\title{
Article \\ Effect of Drying Techniques on the Physical, Functional, and Rheological Attributes of Isolated Sunflower Protein and Its Hydrolysate
}

\author{
Mokhtar Dabbour ${ }^{1,2, *}$, Rokkaya Sami ${ }^{3, *}{ }^{-1}$, Benjamin K. Mintah ${ }^{4}$, Ronghai He ${ }^{1, *}$, Hafida Wahia ${ }^{1}$, \\ Ebtihal Khojah ${ }^{3}$, Anka Trajkovska Petkoska ${ }^{5}$ (D) and Mohammad Fikry ${ }^{2}$ (D) \\ 1 School of Food and Biological Engineering, Jiangsu University, Zhenjiang 212013, China; \\ hafida.wahia.iaa@gmail.com \\ 2 Department of Agricultural and Biosystems Engineering, Faculty of Agriculture, Benha University, \\ Moshtohor, Qaluobia 13736, Egypt; moh.eltahlawy@fagr.bu.edu.eg \\ 3 Department of Food Science and Nutrition, College of Sciences, Taif University, P.O. Box 11099, \\ Taif 21944, Saudi Arabia; eykhojah@tu.edu.sa \\ 4 CSIR—Food Research Institute, Accra P.O. Box M20, Ghana; b.minta20@gmail.com \\ 5 Faculty of Technology and Technical Sciences, St. Kliment Ohridski University-Bitola, Dimitar Vlahov, \\ 1400 Veles, North Macedonia; anka.trajkovska@uklo.edu.mk \\ * Correspondence: mokhtar.dabbour@fagr.bu.edu.eg (M.D.); rokayya.d@tu.edu.sa (R.S.); \\ heronghai1971@126.com (R.H.)
}

check for

updates

Citation: Dabbour, M.; Sami, R.;

Mintah, B.K.; He, R.; Wahia, H.;

Khojah, E.; Petkoska, A.T.; Fikry, M. Effect of Drying Techniques on the

Physical, Functional, and Rheological Attributes of Isolated Sunflower Protein and Its Hydrolysate. Processes 2022, 10, 13. https://doi.org/ $10.3390 /$ pr10010013

Academic Editor: Michaela Schmitz

Received: 29 November 2021

Accepted: 20 December 2021

Published: 22 December 2021

Publisher's Note: MDPI stays neutral with regard to jurisdictional claims in published maps and institutional affiliations.

Copyright: (C) 2021 by the authors. Licensee MDPI, Basel, Switzerland. This article is an open access article distributed under the terms and conditions of the Creative Commons Attribution (CC BY) license (https:// creativecommons.org/licenses/by/ $4.0 /)$.

\begin{abstract}
The influence of freeze and convection (at 40 and $50{ }^{\circ} \mathrm{C}$ ) drying on the physical, functional, and rheological attributes of sunflower protein (SP) and its hydrolysate (SPH) was investigated. Compared with convectively-dried samples, the lightness, turbidity, bulk density, and particle size values of the freeze-dried SP and SPH were substantially higher, but the browning index was lower $(p<0.05)$. Additionally, freeze-dried samples exhibited good solubility and foaming characteristics, whereas lower emulsion properties with the most $\mathrm{pH}$ values were observed. Furthermore, SPHs possessed higher solubility as well as foamability over SPs under varying $\mathrm{pH}$ values (2.0-10.0), whilst reduction in the emulsion activity index was clearly observed $(p<0.05)$. Convectively-dried powders exhibited greater viscosity and consistency coefficient; and significantly lower flow behavior index of dispersions, relative to the respective freeze-dried preparations, indicating that dehydration methods influenced the flow behavior of the investigated samples. From a molecular weight analysis, convectively-dried samples at various temperatures were characterized with high proportion of small-sized particles at $\leq 1 \mathrm{kDa}$ fractions over the respective powders obtained by freeze drying. The observations made, thus, would benefit food processors and manufacturers in electing better dehydration technique based on the desired traits of SP and SPH powders for successful application in food product formulations.
\end{abstract}

Keywords: sunflower protein; freeze drying; convection drying; turbidity; functionality; viscosity; molecular weight

\section{Introduction}

The recent increase in awareness of the nutritional and functional benefits of animal and/or vegetable protein, by the global populace, has resulted in a commensurate increase in the use of the macromolecule (in human diet). Production of vegetable proteins, in contrast with animal proteins, requires less land, fossil energy and water resources; and thus, make it more sustainable [1]. Soy protein is currently the most available plant proteins worldwide. To meet future demands of a more affordable, diverse, and high-quality plant protein, other protein resources must (as matter of importance) be explored. Sunflower, an important oilseed crop in the world, is largely cultivated on five continents (Asia, Africa, Europe, North and South America) with production of 56.07 million tons in 2019 [2]. Two 
main products are obtained from sunflower seeds which are, first, oil (mostly utilized for human nutrition) and, second, meal (primarily underexploited/considered as waste-product). Sunflower meal contains a high content of protein (300 to $500 \mathrm{~g} / \mathrm{kg}$ ), which indicates good potential for use as cheap and sustainable protein source [3]. Sunflower protein (SP) is low in anti-nutritional substances (e.g., cyanogens, protease inhibitors, lectins, and goitrogenic factors), and is devoid of toxic compounds [4], and its amino acids composition (except lysine) complies mainly with the FAO recommendation [5], making it an alternative source of protein. Literature also indicates that sunflower protein/hydrolysate has various bioactivate functions including ACE-inhibition [6], antioxidant [7], and antimicrobial [8] activities. Additionally, the functionalities of SP are close to soy protein, making it a substantial and sustainable natural protein-resource for new food formulations.

The functionalities of proteins are important indicators for food preparation, processing, and consumption. Native SP (from the meal), however, does not have desirable functional traits (such as solubility), observably under its isoelectric point due to the heating steps used throughout oil extraction from the seed [9]. Efforts to enhance the technofunctionalities of SP applying physical [9], chemical [10] and enzymatic approaches [11] are reported. Application of proteolysis (enzymolysis) is essentially considered a suitable and valuable approach for enhancing the functionality of native proteins and keeping their nutritive attributes by preparing peptides with high antioxidative action $[12,13]$.

Furthermore, successful application of protein and/or hydrolysate in food processing basically relies on their functionality, which are mainly dependent on the dehydration/drying techniques. Dehydration techniques (including freeze and convection oven drying) are vital in the preparation of protein and hydrolysate powders aimed at prolonging their shelf-life, and reducing transportation and handling/storage costs. Freeze drying (FD), named as cryodesiccation or lyophilization, is a sophisticated drying method, which includes three (3) stages: freezing, sublimation, and thereafter desorption. FD minimizes the microbiological reactions and ceases most of the deterioration [14], as well as prevents denaturation and the Maillard reaction of protein/hydrolysate [15]. This technique, therefore, is generally used for dehydrating heat-sensitive materials (e.g., protein/hydrolysate) to analyze the physicochemical attributes and functionality/bioactivity of such materials. Convection drying is a comparatively low-cost technique and the dehydration can be performed below the denaturation temperature of proteins, but the residence dehydration time is much longer [16]. However, these drying techniques may, characteristically, induce the limited denaturation of proteins by altering their structures differently and, likewise, impact the functionality and bioactivity of the proteins and/or hydrolysates. It has, previously, been indicated that dehydration techniques have remarkable effects on the rheological, functional, and structural traits of lentil [17], peanut [18], and mung bean [16] protein, as well as egg white hydrolysate [19]. Understanding the alterations in physical, and rheological attributes of protein/hydrolysate and connecting them with the changes in functionality provide strong insights on their behavior during food formulation. Nevertheless, to date, no comparative investigation with in-depth information/analysis on the characteristics of SP and its hydrolysate as affected by various drying procedures has been reported. Motivated by this background, this study compares the impact of two dehydration techniques (freeze and convection oven drying) on the physical, functional, and rheological traits of SP and its hydrolysate.

\section{Materials and Methods}

\subsection{Materials}

Alkaline protease 2.4 LFG (150,000 U/mL activity), which was used to prepare the SP hydrolysates (SPHs) was acquired from Novozymes Bio-Technology Company Ltd. (Tianjing, China). Sunflower meal/by-product was generously obtained from Xinjiang Jinhai Oil Company Ltd. (Xinjiang, China). The by-product was powdered (to $\leq 60$-mesh size) using a DFT-100A portable mill, then kept in zip bags $\left(4^{\circ} \mathrm{C}\right)$ for other processing. The content of SP in the meal was $29.31 \%$ (Kjeldahl method). 


\subsection{Preparation of $S P$ and $S P H$}

SP was isoelectrically ( $\mathrm{pH} 4.5$ ) precipitated and extracted as detailed (earlier) in our research [20] with slight changes. Following extraction, SP suspension was first divided into two (2) equal aliquots. The first aliquot was brought to $\mathrm{pH} 7.0$ and then subjected to various dehydration techniques (Section 2.3) to produce dried SPs. The second aliquot was hydrolyzed $\left(50^{\circ} \mathrm{C}, \mathrm{pH} 9.0\right.$, alkaline protease $0.32 \mathrm{~mL} / \mathrm{LSP}$-suspension, impeller agitator $100 \mathrm{rpm}$ and $90 \mathrm{~min}$ ) as outlined previously in our study [21]. The $\mathrm{pH}$ was set by $1.0 \mathrm{M}$ sodium hydroxide. After proteolysis of SP, the enzyme action was terminated (15 $\mathrm{min}$, $90{ }^{\circ} \mathrm{C}$ ). Hydrolysates (at $19.92 \%$ degree of hydrolysis) were neutralized (at $25{ }^{\circ} \mathrm{C}$ ), centrifuged (5810 R, Eppendorf AG Barkhausenweg 122339, Hamburg, Germany-5000 rpm, $15 \mathrm{~min}$ ), and thereafter the supernatants ( $\mathrm{pH} 7.0$ ) were dried (Section 2.3).

\subsection{Drying Process of SP and SPH}

Two drying techniques (freeze drying and convection oven drying) were applied to dehydrate the SP and SPH solutions. To prepare the freeze-dried powder (with $\leq 5 \%$ moisture content), SP and SPH suspensions were first frozen $(24 \mathrm{~h})$ on petri dishes at $-18{ }^{\circ} \mathrm{C}$, and afterward lyophilized (for $\sim 48 \mathrm{~h}$ ) under $0.096 \mathrm{mBar}$ vacuum at $-81^{\circ} \mathrm{C}$ using a Lyo-Quest-85-Plus freeze dryer (Telstar Lyo-Quest, Spain).

Convection oven drying was conducted at two different temperatures using a ventilated air-drying oven (DHG-9123A, Blue Pard, Shanghai Yiheng Scientific company Ltd., Shanghai, China). The temperature was set at 40 and $50{ }^{\circ} \mathrm{C}$ (for $\sim 60$ and $48 \mathrm{~h}$, respectively to realize a moisture content $\leq 5 \%$ in the dried samples). Air velocity/circulation was $1.0 \mathrm{~m} / \mathrm{s}$. The basis for selecting these drying temperatures was due to the fact that the lower temperature $\left(<40^{\circ} \mathrm{C}\right)$ was noted to extend the dehydration time resulting in microbial spoilage, and the higher temperature $\left(>50^{\circ} \mathrm{C}\right)$ could negatively affect the functionality and bioactivity of samples. Resulting SP and SPH powders were pulverized (to $\leq 40$-mesh size) using a DFT-100A portable mill, then kept at $-20^{\circ} \mathrm{C}$ for characterization.

\subsection{Analysis of Color and Browning Index ( $B_{\text {index }}$ )}

Color traits (including $L^{*}, a^{*}$ and $b^{*}$ ) of all dried samples were examined with CR-400 colorimeter (Hangzhou Ke Sheng Instrument Company Ltd., Osaka, Japan). The L* is the luminosity/lightness component, varying from 0 (black) to 100 (white), $\mathrm{a}^{*}$ and $\mathrm{b}^{*}$ values range from -100 to +100 green $(-) /$ red $(+)$ and blue $(-)$ /yellow $(+)$, respectively.

$B_{\text {index }}$ was estimated as outlined by the method of Ding and Ling [22] applying Equation (1):

$$
\mathrm{B}_{\text {index }}=\frac{\mathrm{N}-0.31}{0.172} \times 100
$$

where

$$
\mathrm{N}=\frac{\mathrm{a}^{*}+1.75 \mathrm{~L}^{*}}{5.65 \mathrm{~L}^{*}+\mathrm{a}^{*}-0.301 \mathrm{~b}^{*}}
$$

\subsection{Particle Sizing $\left(P_{\text {sizing }}\right)$ and Bulk Density ( $\left.B_{\text {density }}\right)$}

The $\mathrm{P}_{\text {sizing }}$ of SPs and hydrolysates (SPHs) was quantified (at $23 \pm 1^{\circ} \mathrm{C}$ ) using an Anton Litesizer-500 (Austria). Freeze and oven-dried SP and SPH were dissolved in distilled $\mathrm{H}_{2} \mathrm{O}(1 \mathrm{mg} / \mathrm{mL}, \mathrm{pH} 7.0)$ before determining $\mathrm{P}_{\text {sizing. }}$.

$\mathrm{B}_{\text {density }}$ was determined by transferring the dehydrated samples $(5 \mathrm{~g})$ into graduated cylinders $(25 \mathrm{~mL})$ and tapped gently until the volume of SP and SPH remained constant. The volume was estimated, and the $B_{\text {density }}$ was thereafter recorded as $\mathrm{g} / \mathrm{mL}$.

\subsection{Turbidity}

The turbidity $\left(\mathrm{T}_{\text {tur }}\right.$ ) of SP and SPH solutions $(1.4 \mathrm{mg} / \mathrm{mL}$ in $0.05 \mathrm{M}(\mathrm{pH} 7.0)$ phosphate buffer) was assayed by determining the absorbance at an ambient temperature using a spectrophotometer at $600 \mathrm{~nm}$. The absorbance was then utilized as a $\mathrm{T}_{\text {tur }}$ index [13]. 


\subsection{Protein Solubility}

Solubility $\left(\mathrm{P}_{\text {solubility }}\right)$ of SP and SPH suspensions $(3.0 \%, w / v)$ was assessed under varying $\mathrm{pH}$ from 2.0 to 12.0 . The respective dispersions (solubilized) were subjected to centrifugation (15 min, $4000 \mathrm{rpm}$ ), and the amount of protein was assayed in supernatants through the protocol described by Lowry and colleagues [23]. Bovine serum albumin was employed as the standard.

\subsection{Foaming Attributes}

Foaming capacity $\left(\mathrm{F}_{\text {capacity }}\right)$ and foam stability $\left(\mathrm{F}_{\text {stability }}\right)$ of SP and SPH solutions (4 $\mathrm{g}$ in $100 \mathrm{~mL}$ distilled $\mathrm{H}_{2} \mathrm{O}$ ) were examined under varied $\mathrm{pH}(2.0-12.0)$. Respective suspensions were blended (at 10,000 rpm) using FSH-2A-homogenizer (Fang Ke Instrument (Changzhou) Company Ltd., Jiangsu, China) for $5 \mathrm{~min}$, and transferred immediately into calibrated cylinders. The total volume of the resultants (after $30 \mathrm{~s}$ and $20 \mathrm{~min}$ ) was recorded to quantify $\mathrm{F}_{\text {capacity }}$ and $\mathrm{F}_{\text {stability, }}$, respectively. Computation was performed by the following Equations (3) and (4):

$$
\begin{gathered}
\mathrm{F}_{\text {capacity }}(\%)=\frac{\text { Volume after whipping }(30 \mathrm{~s})-\text { Initial volume }}{\text { Initial volume }} \times 100 \\
\mathrm{~F}_{\text {stability }}(\%)=\frac{\text { Volume after whipping }(20 \mathrm{~min})-\text { Initial volume }}{\text { Initial volume }} \times 100
\end{gathered}
$$

\subsection{Emulsion Properties}

Emulsion activity index $\left(\mathrm{EA}_{\text {index }}\right)$ and emulsion stability index $\left(\mathrm{ES}_{\text {index }}\right)$ of samples (SPs and SPHs) were measured with the method of Liu et al. [24] with slight alterations. Five milliliters of sunflower oil and $15 \mathrm{~mL}$ of $(1 \%)$ sample dispersions under varied $\mathrm{pH}$ (2.0-12.0) were homogenized (FSH-2A, Fang Ke Instrument (Changzhou) Company Ltd., Jiangsu, China) for $1 \mathrm{~min}$ (at 10,000 rpm). The aliquot of the emulsion $(100 \mu \mathrm{L})$ was directly picked from the bottom of the tube and mixed with SDS $(10 \mathrm{~mL}, 0.1 \%)$ at zero and $10 \mathrm{~min}$ after homogenization. Absorbance of the resultant (at $500 \mathrm{~nm}$ ) was analyzed at zero min $\left(\mathrm{S}_{0}\right)$ and $10 \mathrm{~min}\left(\mathrm{~S}_{10}\right)$ subsequent to emulsion formation using spectrophotometer. $\mathrm{EA}_{\text {index }}$ and $\mathrm{ES}_{\text {index }}$ were computed as:

$$
\begin{gathered}
\mathrm{EA}_{\text {index }}\left(\mathrm{m}^{2} / \mathrm{g}\right)=\frac{2 \times 2.303 \times 100 \times \mathrm{S}_{0}}{10000 \times 0.25 \times \mathrm{P}_{\mathrm{c}}} \\
\mathrm{ES}_{\text {index }}(\mathrm{min})=\frac{\mathrm{S}_{0} \times 10}{\mathrm{~S}_{0}-\mathrm{S}_{10}}
\end{gathered}
$$

where $\mathrm{P}_{\mathrm{c}}(\mathrm{g} / \mathrm{mL})$ depicts SP and SPH concentration.

\subsection{Apparent Viscosity $\left(A_{\text {viscosity }}\right)$ and Shear Stress ( $\left.S_{\text {stress }}\right)$}

The $\mathrm{A}_{\text {viscosity }}$ and $\mathrm{S}_{\text {stress }}$ of $\mathrm{SP}$ and $\mathrm{SPH}$ suspensions $\left(1 \mathrm{mg} / \mathrm{mL}\right.$ in deionized $\left.\mathrm{H}_{2} \mathrm{O}\right)$ were examined using a DHR-1-rheometer (Waters ${ }^{\mathrm{TM}}$, TA Instruments Company, New Castle, DE, USA). The DHR-1-rheometer parameters were set at duration $120.0 \mathrm{~s}, 2{ }^{\circ} \mathrm{C}$, linear mode, shear rate from 0.01 to $100.0 \mathrm{~s}^{-1}$ and test interval of $1000 \mu \mathrm{m}$. The correlation among the shear rate and shear stress was modeled by applying the power law equation [25] as follows:

$$
\tau=\mathrm{K} \gamma^{n}
$$

where $\tau(\mathrm{Pa})$ represents shear stress; $\gamma(1 / \mathrm{s})$ represents shear rate; $\mathrm{K}$ (Pa.s) represents consistency coefficient; and $\mathrm{n}$ depicts flow behavior/attribute index.

\subsection{Molecular Weight $\left(M_{\text {Weight }}\right)$ Distribution}

Following the procedure of Wang et al. [26] with minor modifications, HPLC system (1525-Waters, Thermo. Scientific Inc., Waltham, MA, USA; TSKgel SWXL-2000, 
$30 \times 0.78 \mathrm{~cm}$; Tosoh, Japan) was utilized to characterize the $\mathrm{M}_{\text {weight }}$ distribution of freezeand oven-dried SP and SPH. Respective suspensions were eluted (flow rate- $1.0 \mathrm{~mL} / \mathrm{min}$ ) at $220 \mathrm{~nm}$. Standards with known $\mathrm{M}_{\text {weight }}$ were applied for the calibration curve: bovine serum albumin $(67,000 \mathrm{Da})$, peroxidase $(40,200 \mathrm{Da})$, ribonuclease A $(13,700 \mathrm{Da})$, glycine tetramer (246 Da) and p-aminobenzoic acid (137.14 Da). The SP and SPH were separated into six (6) fractions: $\mathrm{M}_{\text {weight }}>10,000,10,000-5000,5000-3000,3000-1000,1000-500$, and $<500 \mathrm{Da}$, and the content of the fractions expressed in percent $(\%)$.

\subsection{Statistical Analysis}

Experimental results (in triplicates) were subjected to ANOVA by Minitab (Version 18.0, Minitab Inc., Pennsylvania, PA, USA) to assay the differences (at $p<0.05$ ) in averages following various dehydration methods. Pearson's correlation (by XLSTAT-V1.0-2016 software-XLSTAT Inc., New Yourk, NY, USA) was performed to quantify the interrelation between the physical, functional, and rheological parameters.

\section{Results and Discussion}

\subsection{Physical Attributes}

Color property plays a substantial sensory role in the acceptability of plant proteins (e.g., SP and its hydrolysate) for food preparations. Color attributes of SP and SPH prepared by freeze and convection $\left(40\right.$ and $\left.50{ }^{\circ} \mathrm{C}\right)$ drying were presented in Table 1. Remarkable changes were recorded $(p<0.05)$ in the color parameters (noticeably L*) of dried SPs and their hydrolysates (SPHs), suggesting that the color of dried samples was influenced by dehydration techniques and enzymolysis. Among the dried samples, freeze-dried SP (FDSP) and SPH (FDSPH) were noted to be lighter than the other respective powders obtained by convective drying under varied temperatures. The convectively-dried (CD) $\mathrm{SP}$ and SPH (especially at $50{ }^{\circ} \mathrm{C}$ ) showed maximal $a^{*}$ and $b^{*}$, and consequently the least $\mathrm{L}^{*}$ values, reference to the freeze-dried (FD) samples; illustrating the $\mathrm{CD}$ powders were darker. These observations are possibly linked to the oxidation of the convectively-dried SP and SPH due to the direct contact between samples and oxygen $\left(\mathrm{O}_{2}\right)$ under high temperature throughout the drying time. This also may be ascribed to the low temperature, pressure and $\mathrm{O}_{2}$ in freeze drying, contributing to high luminosity. Such findings were also indicated for chickpea protein in earlier research [27]. Furthermore, the $\mathrm{L}^{*}$ value of dehydrated powders was notably reduced $(p<0.05)$ from $50.82 \pm 0.89$ to $38.27 \pm 0.12$ (for freeze-dried SP), $42.36 \pm 0.43$ to 34.12 (for $\mathrm{CDSP}_{40}$ ) and $37.25 \pm 0.45$ to $30.48 \pm 0.31$ (for $\mathrm{CDSP}_{50}$ ) following proteolysis, indicating loss of luminosity. The reduction in luminosity is possibly correlated with unfavorable chemical modifications during enzymatic hydrolysis (such as Maillard reaction- $\mathrm{R}_{\text {Maillard }}$ [28,29]. This can clarify the noticeable decrease in luminosity of SPHs (particularly convectively-dried $\mathrm{SPH}$ at $50{ }^{\circ} \mathrm{C}-\mathrm{CDSPH}_{50}$ ). This outcome is also consistent with the higher $\mathrm{B}_{\text {index }}$ (Table 1) for the freeze- and convectively-dried SPH compared with the dehydrated SPs. Finally, such results indicated that freeze drying was the most efficient technique in controlling the Maillard reaction and the luminosity of the samples.

Table 1 shows the browning index of SP and SPH obtained by different dehydration techniques. Results indicated that FDSP isolate displayed a lower $(p<0.05) B_{\text {index }}$ than the remaining samples. Contrarily, $\mathrm{CDSPH}_{50}$ had the highest browning intensity implying it was the darkest among the other preparations. Moreover, the $B_{\text {index }}$ of freeze and convectively (at 40 and $50{ }^{\circ} \mathrm{C}$ ) dried $\mathrm{SPH}$ was respectively 59.60, 53.45, and $54.07 \%$ greater than FDSP, $\mathrm{CDSP}_{40}$, and $\mathrm{CDSP}_{50}$. The high $\mathrm{B}_{\text {index }}$ of the $\mathrm{SPH}$ (notably $\mathrm{CDSPH}_{50}$ ), relative to the remaining powders, can be attributed to the fact that the enzymolysis and convective drying accelerated the interaction of aldehydes and free amino clusters via $R_{\text {Maillard, induc- }}$ ing a browner product than the other samples. Similar observation regarding the effect of convection oven drying on $B_{\text {index }}$ of mung bean protein has been reported [16]. The intense $R_{\text {Maillard }}$ in the convectively-dried hydrolysates was further confirmed by its high $B_{\text {index }}$ (Table 1). 
Table 1. Physical traits of freeze and convectively (oven)-dried SP and SPH.

\begin{tabular}{|c|c|c|c|c|c|c|c|}
\hline \multicolumn{2}{|c|}{ Property } & FDSP & $\mathrm{CDSP}_{40}$ & $\mathrm{CDSP}_{50}$ & FDSPH & $\mathrm{CDSPH}_{40}$ & $\mathrm{CDSPH}_{50}$ \\
\hline \multirow{3}{*}{ Color } & $L^{*}$ & $50.82 \pm 0.89^{a}$ & $42.36 \pm 0.43^{b}$ & $37.25 \pm 0.45^{c}$ & $38.27 \pm 0.12^{c}$ & $34.12 \pm 1.08^{\mathrm{d}}$ & $30.48 \pm 0.31^{\mathrm{e}}$ \\
\hline & $a^{*}$ & $0.38 \pm 0.04^{\mathrm{d}}$ & $0.50 \pm 0.01^{c}$ & $0.56 \pm 0.05^{c}$ & $0.79 \pm 0.02^{b}$ & $0.86 \pm 0.03^{b}$ & $0.94 \pm 0.02^{\mathrm{a}}$ \\
\hline & $b^{*}$ & $3.84 \pm 0.08^{\mathrm{d}}$ & $4.10 \pm 0.09^{\mathrm{d}}$ & $4.59 \pm 0.23^{\mathrm{cd}}$ & $5.56 \pm 0.45^{b c}$ & $6.42 \pm 0.31^{b}$ & $7.86 \pm 0.72^{\mathrm{a}}$ \\
\hline \multicolumn{2}{|c|}{$\mathrm{B}_{\text {index }}$} & $1.10 \pm 0.05^{\mathrm{f}}$ & $1.61 \pm 0.01^{\mathrm{e}}$ & $2.09 \pm 0.10^{\mathrm{d}}$ & $2.72 \pm 0.13^{c}$ & $3.46 \pm 0.03^{b}$ & $4.55 \pm 0.19^{a}$ \\
\hline \multicolumn{2}{|c|}{$\mathrm{P}_{\text {sizing }}$} & $548.61 \pm 21.93^{a}$ & $456.11 \pm 23.80^{b}$ & $397.86 \pm 3.70^{c}$ & $388.55 \pm 15.69^{c}$ & $304.17 \pm 16.99^{d}$ & $280.71 \pm 6.47^{d}$ \\
\hline \multicolumn{2}{|c|}{$\mathrm{B}_{\text {density }}$} & $395.27 \pm 2.73^{a}$ & $336.24 \pm 6.24^{b}$ & $312.92 \pm 1.92^{\mathrm{c}}$ & $290.86 \pm 2.85^{d}$ & $275.45 \pm 3.55^{\mathrm{e}}$ & $258.74 \pm 2.16^{f}$ \\
\hline \multicolumn{2}{|c|}{$\mathrm{T}_{\text {tur }}$} & $0.87 \pm 0.015^{a}$ & $0.68 \pm 0.003^{b}$ & $0.66 \pm 0.005^{b}$ & $0.42 \pm 0.008^{c}$ & $0.33 \pm 0.011^{\mathrm{d}}$ & $0.29 \pm 0.003^{\mathrm{e}}$ \\
\hline
\end{tabular}

Note: Results (average of three (3) times) in one row with various letter-superscript exhibit significantly different $(p<0.05)$. FDSP: freeze-dried sunflower protein; CDSP40: convectively-dried sunflower protein at $40{ }^{\circ} \mathrm{C}$; CDSP50: convectively-dried sunflower protein at $50{ }^{\circ} \mathrm{C}$; FDSPH: freeze-dried sunflower protein hydrolysate; $\mathrm{CDSPH} 40$ convectively-dried sunflower protein hydrolysates at $40^{\circ} \mathrm{C}$; CDSPH50: convectively-dried sunflower protein at $50{ }^{\circ} \mathrm{C}$.

For the $\mathrm{P}_{\text {sizing }}$ of the $\mathrm{SP}$ and $\mathrm{SPH}$ powders (Table 1), all the samples had $\mathrm{P}_{\text {sizing }}$ lower than $550 \mathrm{~nm}$. Freeze-dried SP and SPH showed higher $\mathrm{P}_{\text {sizing }}(548.61 \pm 21.93$ and $388.55 \pm 15.69 \mathrm{~nm}$, respectively) than convectively-dried samples $(p<0.05)$. This phenomenon can be linked to the formation of ice crystal(s), inducing the aggregates of particles and recombining into bigger $P_{\text {sizing }}$ during the lyophilization [30], thus FDSP and FDSPH showed the highest $\mathrm{P}_{\text {sizing }}$ over the respective CDSP and CDSPH under varied temperatures. Further, lower $\mathrm{P}_{\text {sizing }}$ values $(p<0.05)$ were observed for dehydrated SPHs (especially $\mathrm{CDSPH}_{50}-280.71 \pm 6.47 \mathrm{~nm}$ ) with reference to the SP powders. This implied that enzymolysis caused a breakdown of SP molecules (as supported by the observations of $\mathrm{M}_{\text {weight }}$ analysis (Section 3.6), resulting in the release and/or formation of small-sized peptide(s). Similar outcomes due to freeze and convection oven drying [16,27], as well as enzymolysis [13] on $P_{\text {sizing }}$ were recorded (by other researchers).

The $B_{\text {density }}$ of SPs and their hydrolysates was substantially influenced $(p<0.05)$ by the drying and proteolysis techniques. The highest $B_{\text {density }}\left(395.27 \pm 2.73 \mathrm{~kg} / \mathrm{m}^{3}\right)$ was noticed for FDSP followed by CDSP $40, \mathrm{CDSP}_{50}, \mathrm{FDSPH}, \mathrm{CDSPH}_{40}$, and $\mathrm{CDSPH}_{50}$ (Table 1). The observed variations can be linked to the dehydration method/temperature, enzymolysis, particle porosity and $\mathrm{P}_{\text {sizing }}$ distribution. The outcomes of $\mathrm{B}_{\text {density }}$ of freezeand convectively-dried SP and SPH were consistent with the observations of $\mathrm{P}_{\text {sizing }}$ of the corresponding samples. Rudra et al. [31] and Joshi et al. [17] observed comparable $B_{\text {density }}$ for freeze-dried cowpea protein $\left(428.5 \mathrm{~kg} / \mathrm{m}^{3}\right)$ and lentil protein $\left(276 \mathrm{~kg} / \mathrm{m}^{3}\right)$, respectively.

The effect of dehydration approaches on the turbidimetric value of SP and SPH is presented in Table 1. In general, turbidities of freeze-dried SP and SPH were markedly higher than the respective convectively-dried powders under varying temperatures $(p<0.05)$. This finding may be credited to the higher $\mathrm{P}_{\text {sizing }}$ of lyophilized samples. On the other hand, freeze- and convectively (at 40 and $50{ }^{\circ} \mathrm{C}$ )-dried SPH had low turbidity values (by $51.72,51.47$ and $56.07 \%)$ compared with the respective SP isolates $(p<0.05)$, consistent with $\mathrm{P}_{\text {sizing }}$ results. This reduction is probably linked to the disordering/unfolding of protein-protein interactions following enzymolysis, which induced formation of peptides with small $\mathrm{P}_{\text {sizing }}$ /aggregates; and this may further elucidate the recorded lower turbidities of the dehydrated SPHs. Low turbidimetric values with lower $P_{\text {sizing }}$ of protein are reported [32]. These outcomes were supported by the discussed observations on $P_{\text {sizing }}$ and $\mathrm{M}_{\text {weight }}$ in this study.

\subsection{Solubility}

$\mathrm{P}_{\text {solubility }}$ is essential in food formulations as it can affect the nutritional value and /or functionality (emulsion, flavor creation, foam, gel, and texture) of protein [33]. To comprehend the differences in the quality of dehydrated SPs and hydrolysates, their solubility under varying $\mathrm{pH}(2.0-12.0)$ was assessed (Figure 1). All preparations exhibited a U-shaped $\mathrm{P}_{\text {solubility }}$ trend (especially the dried SP isolates) with the lowest $\left(\mathrm{P}_{\text {solubility }}\right)$ value at $\mathrm{pH}$ 4.0, consistent with data from other studies [1,12]. Additionally, all samples displayed max- 
imal $\mathrm{P}_{\text {solubility }}$ under extreme alkaline $(\mathrm{pH} 10.0,12.0)$ conditions. This can be ascribed to the increased net charges of samples at $\mathrm{pH} \geq 10.0$, contributing to the dissociation of protein/hydrolysate aggregates which enhanced the protein $-\mathrm{H}_{2} \mathrm{O}$ associations and thus improved $\mathrm{P}_{\text {solubility. }}$. Freeze-dried SP and SPH had notably higher $\mathrm{P}_{\text {solubility }}$ than their respective oven-dried powders (at 40 and $50{ }^{\circ} \mathrm{C}$ ) under varied $\mathrm{pH}(6.0-12.0)$. There was, however, no clear $\mathrm{P}_{\text {solubility }}$ trend amongst the convectively-dried powders at various temperatures

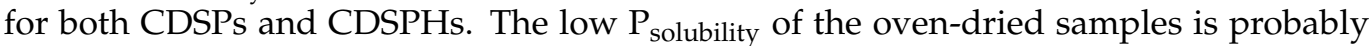
linked to the outer skin (highly $\mathrm{H}_{2} \mathrm{O}$ resistant film) formed at the interface of particle-air due to the unfolding/denaturation of protein through drying [27]. The higher $\mathrm{P}_{\text {solubility }}$ of FD powders is credited to lower denaturation of protein during dehydration, which boosted $\mathrm{H}_{2} \mathrm{O}$-soluble aggregates. Moreover, $\mathrm{P}_{\text {solubility }}$ of the SPHs was a noticeably improved reference to the respective dehydrated SPs under varying $\mathrm{pH}(p<0.05)$. This increase is perhaps, first, associated with their smaller $\mathrm{P}_{\text {sizing }}$ and reduction in $\mathrm{M}_{\text {weight }}$ (as exhibited in Sections 3.1 and 3.6) as well as the freshly formed amine and carboxyl clusters during enzymolysis, contributing to the formation of hydrogen bridges with water, which improved $\mathrm{P}_{\text {solubility }}$ in aqueous suspensions [34]. Secondly, enzymolysis induced the released soluble peptides from in-soluble aggregates. Such observations are comparable to what is found in literature regarding the influence of dehydration techniques [35] and proteolysis [28] on solubility. Based on $\mathrm{P}_{\text {solubility }}$ profiles, freeze-dried powders (particularly FDSPH) would be useful for several functional utilizations in food and/or pharmaceutical industry.

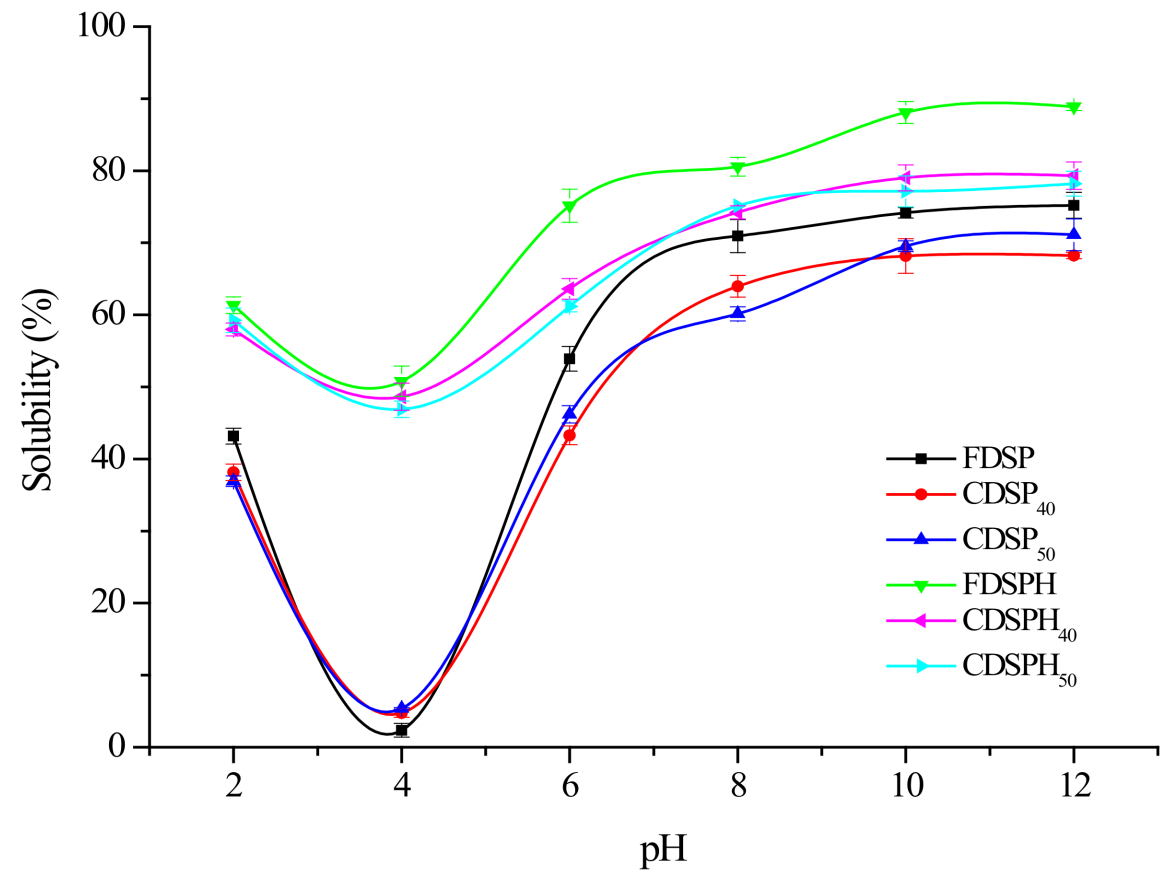

Figure 1. Solubility of freeze- and convectively-dried SP and SPH.

\subsection{Foaming Attributes}

The foaming capacity $\left(\mathrm{F}_{\text {capacity }}\right)$ and stability $\left(\mathrm{F}_{\text {stability }}\right)$ of protein depend mainly on their interaction at interfacial surfaces, which is influenced by molecular flexibility, net charge, conformation and hydrophobicity. Foaming attributes of SPs and SPHs from different dehydration techniques at $\mathrm{pH}$ 2.0-12.0 are displayed in Figure 2A,B. $\mathrm{F}_{\text {capacity }}$ of all dehydrated samples (Figure $2 \mathrm{~A}$ ) was noticeably affected by the drying methods, and $\mathrm{pH}$. All preparations showed low $\mathrm{F}_{\text {capacity }}$ at $\mathrm{pH}$ 6.0, and thereafter substantially improved $(p<0.05)$ on both sides of this $\mathrm{pH}$ value. Additionally, freeze-dried powders exhibited higher $\mathrm{F}_{\text {capacity }}$ values compared with oven-dried samples (remarkably at pH 2.0-6.0 and 10.0), suggesting that FDSP and FDSPH possessed rapid conformational changes at the interface of gas (air) and solvent with a decrease in surface tension. This increase may 
be associated with the improved $\mathrm{P}_{\text {solubility }}$ of FD powders (as displayed in Figure 1) due to increased positive/negative net charges of these samples in solutions [1]. This may as well be ascribed to higher hydrophobicity and molecular flexibility (lower disulfide bridges) of FDSP and FDSPH, stimulating an increase in $\mathrm{F}_{\text {capacity. }}$. Furthermore, freeze- and convectively-dried SPH had higher $\mathrm{F}_{\text {capacity }}$ than the respective SP isolates under varying $\mathrm{pH}(p<0.05)$. Thus, the enzymolysis altered surface-stabilizing subunits with enhanced interaction at the interface of gas-solvent. In addition, enzyme action potentially reduced molecular weight and increased the flexibility/diffusion speed of SPHs, contributing to an increased absorption rate and stabilization of freshly formed foams at the interface, which (then) improved foam expansion [36].
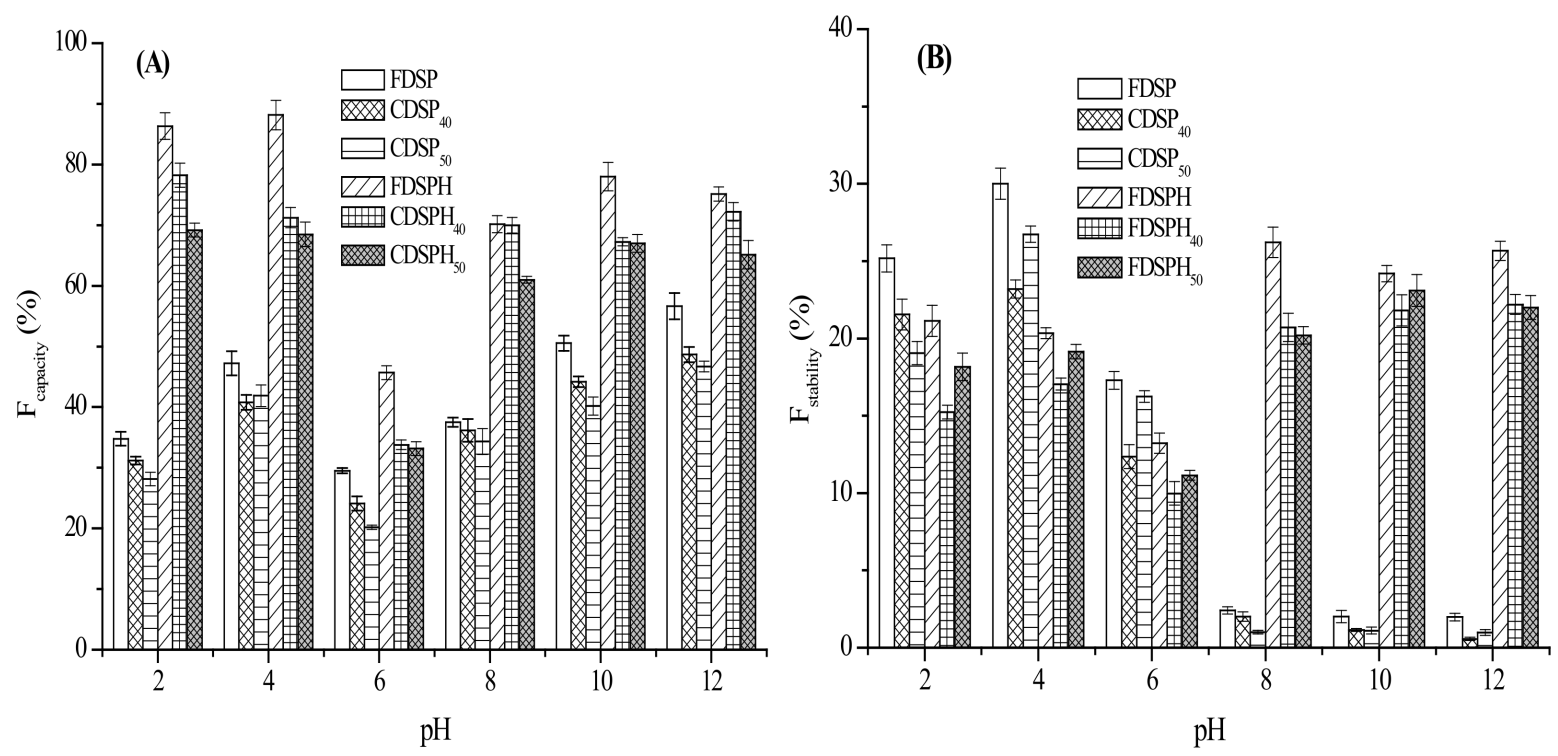

Figure 2. Foaming capacity (A) and stability (B) of freeze- and convectively-dried SP and SPH.

The $\mathrm{F}_{\text {stability }}$ of dehydrated samples were also influenced by drying approaches and $\mathrm{pH}$. Lower $\mathrm{F}_{\text {stability }}$ values of convectively-dried samples at various temperatures were observed with reference to the freeze-dried powders. This may be credited to limited alterations in the protein/hydrolysate molecules, resulting in reduced mechanical strength and/or film thickness of gas-solvent interface, which decreased $\mathrm{F}_{\text {stability. Further, freeze- }}$ and convectively-dried SPH foam were less stable $(p<0.05)$ relative to the respective SP powders under acidic ( $\mathrm{pH}$ 2.0-6.0) conditions. Under alkali $\mathrm{pH}(8.0-12.0)$; however, SPHs presented significantly high $\mathrm{F}_{\text {stability }}$ compared with SP isolates. These changes in $\mathrm{F}_{\text {stablity }}$ under varied $\mathrm{pH}$ suggested that the flexibility of the molecules to migrate/orient at interface of gas-solvent was affected by enzymolysis. There are also (in agreement) reports high $\mathrm{F}_{\text {capacity }}$ and $\mathrm{F}_{\text {stability }}$ of freeze-dried protein $[27,37]$ and enzyme-hydrolyzed protein $[36,38]$. Nonetheless, Zeng et al. [35] observed that oven-dried collagen peptide possessed greater foamability and $\mathrm{F}_{\text {stability }}$ over a freeze-dried sample. This discrepancy can possibly be attributed to the variations in protein fractions and oven drying conditions.

\subsection{Emulsion Traits}

The $\mathrm{EA}_{\text {index }}$ and $\mathrm{ES}_{\text {index }}$ were examined and compared for dehydrated SPs (FDSP, $\mathrm{CDSP}_{40}, \mathrm{CDSP}_{50}$ ), and $\mathrm{SPHs}$ (FDSPH, $\mathrm{CDSPH}_{40}, \mathrm{CDSPH}_{50}$ ) under varied $\mathrm{pH}$ (Figure $3 \mathrm{~A}, \mathrm{~B}$ ). Emulsion profiles of dried SPs and SPHs were in agreement with $\mathrm{P}_{\text {solubility }}$ pattern. All powders (SPs, SPHs) exhibited lower $\mathrm{EA}_{\text {index }}$ and $\mathrm{ES}_{\text {index }}$ at isoelectric $\mathrm{pH}(4.0)$, whilst the higher values were recorded under alkaline $\mathrm{pH}$. The reason may be that protein/hydrolysate could not migrate rapidly to the oil- $\mathrm{H}_{2} \mathrm{O}$ interface, and/or the isoelectric $\mathrm{pH}$ caused the precipitation of macro-molecules of SPs and SPHs and reduction in net charges of macro-molecules, and consequently impairing the emulsification attributes. Such obser- 
vations were also noted, with regards to the impact of $\mathrm{pH}$ on emulsion attributes of egg white hydrolysate [19]. Furthermore, in comparison with the convectively-dried preparations at various temperatures, notably lower $\mathrm{EA}_{\text {index }}$ and $\mathrm{ES}_{\text {index }}$ of FD samples (FDSP, FDSPH), at alkaline $\mathrm{pH}, p<0.05$, were observed. However, no difference (at most $\mathrm{pH}$ values $-p>0.05$ ) was observed amongst the oven-dried samples (at $40^{\circ} \mathrm{C}$ ) and the respective dehydrated powders $\left(\right.$ at $50^{\circ} \mathrm{C}$ ). The low emulsifying activity/stability values of lyophilized samples are possibly linked to the reduction in hydrophobic/hydrophilic clusters and the charges of FD samples, impairing oil-in- $\mathrm{H}_{2} \mathrm{O}$ emulsion. The higher $\mathrm{EA}_{\text {index }}$ and $\mathrm{ES}_{\text {index }}$ values of $\mathrm{CD}$ powders could as well be correlated with the partial denaturation of protein/hydrolysate by heating throughout oven drying (at 40 and $50{ }^{\circ} \mathrm{C}$ ), inducing the exposure of hydrophilic/hydrophobic amino acids to the peripheral environment which promoted the adsorption capacity at oil- $\mathrm{H}_{2} \mathrm{O}$ interface.
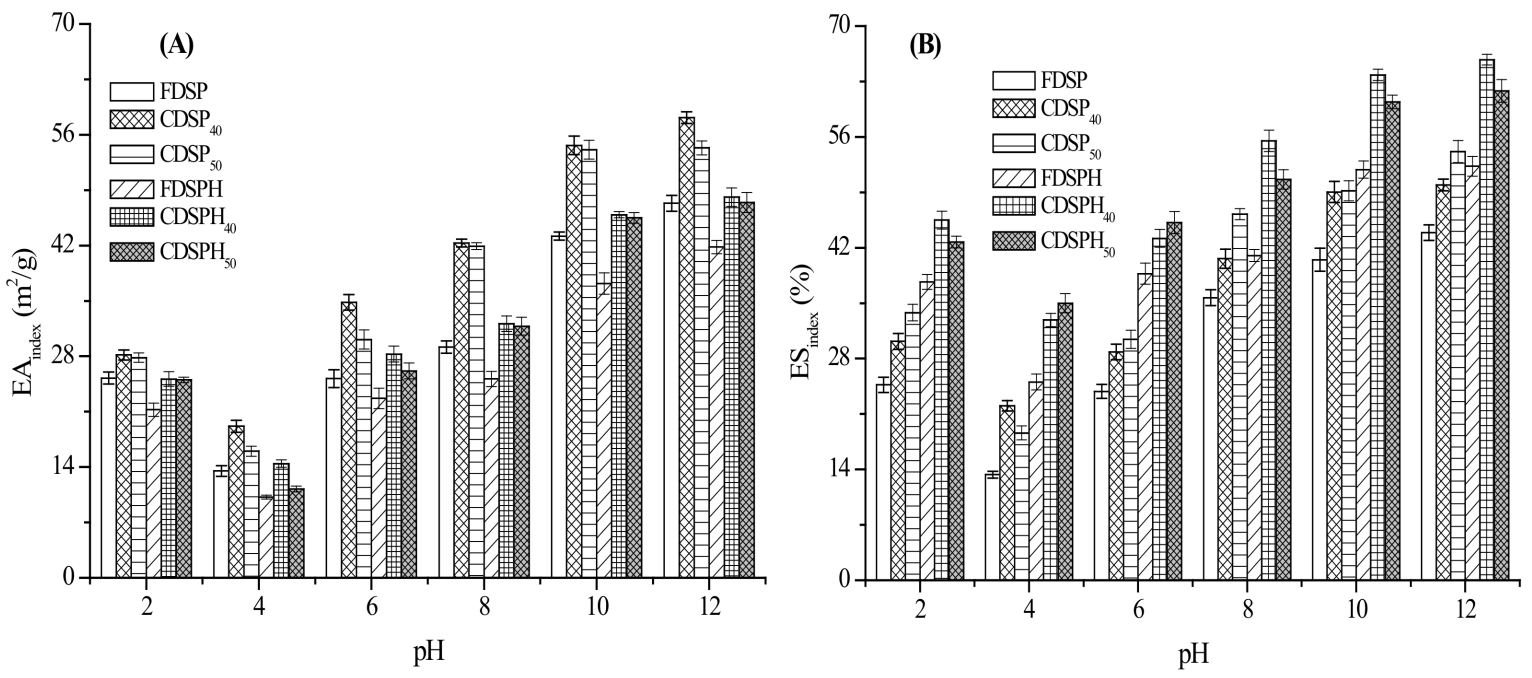

Figure 3. $\mathrm{EA}_{\text {index }}(\mathbf{A})$ and $\mathrm{ES}_{\text {index }}(\mathbf{B})$ of freeze- and convectively-dried SP and SPH.

Results also showed that SPHs possessed low $\mathrm{EA}_{\text {index }}$, but high $\mathrm{ES}_{\text {index }}$ values compared with the respective SP isolates $(p<0.05)$. The low $\mathrm{EA}_{\text {index }}$ of SPHs can be associated with the formation of small-sized hydrolysates (peptides) during the enzymolysis. These hydrolysates were diffused and adsorbed rapidly at oil $/ \mathrm{H}_{2} \mathrm{O}$ interface, but thereafter exhibited reduced efficiency in decreasing interfacial tension because they were not unfolded and/or rearranged at the interface, which reduced the $\mathrm{EA}_{\text {index }}$ [39]. Moreover, a higher $\mathrm{ES}_{\text {index }}$ value of SPHs suggested that these hydrolysates were more stable at oil- $\mathrm{H}_{2} \mathrm{O}$ interface and were sufficiently flexible to generate good interfacial films, contributing to enhancing emulsion stability [35]. In literature, Elavarasan and Shamasundar [40], and Ghribi et al. [27] indicated that oven drying resulted in greater $\mathrm{EA}_{\text {index }}$ and $\mathrm{ES}_{\text {index }}$ of protein/hydrolysate than the respective freeze-dried samples, which was in agreement with the noted outcomes in this study. Contrarily, Brishti et al. [16], and Musa et al. [41] found that FD samples had higher emulsion traits $\left(\mathrm{EA}_{\text {index }}, \mathrm{ES}_{\text {index }}\right)$ over convectivelydried powders. This difference can be associated with the variations in protein properties and processing conditions (e.g., drying time and temperature).

\subsection{Rheological Analysis}

Rheological traits (mainly viscosity) play a crucial role in the texture or mouth-feel of food beverages, as well as in processes such as extrusion and pumping. Lower viscosity for hydrolysate/protein solutions is desirable for piping and pumping, whereas higher viscosity can aid the preparation of sausage/meat analogs and/or used as thickener for soups [14]. For better comprehension of the variations in the behavior of dehydrated SPs and hydrolysates in food system, their rheological attributes following various dehydration techniques were assayed, and the results are presented in Figures 4 and 5 and in Table 2. 
Viscosity of SPs and SPHs (Figure 4) reduced with increased shear rate (representing shear thinning behavior). The reason can be that, the deformation and disruption of aggregated network of SPs and SPHs suspensions with shear rate (from 2 to $100 \mathrm{~s}^{-1}$ ), which reduced the viscosities [42]. This is, also, mostly correlated with the orientation of particles and molecules due to increased shear rate to be substantially more than random motion impact generated by the Brown effect.

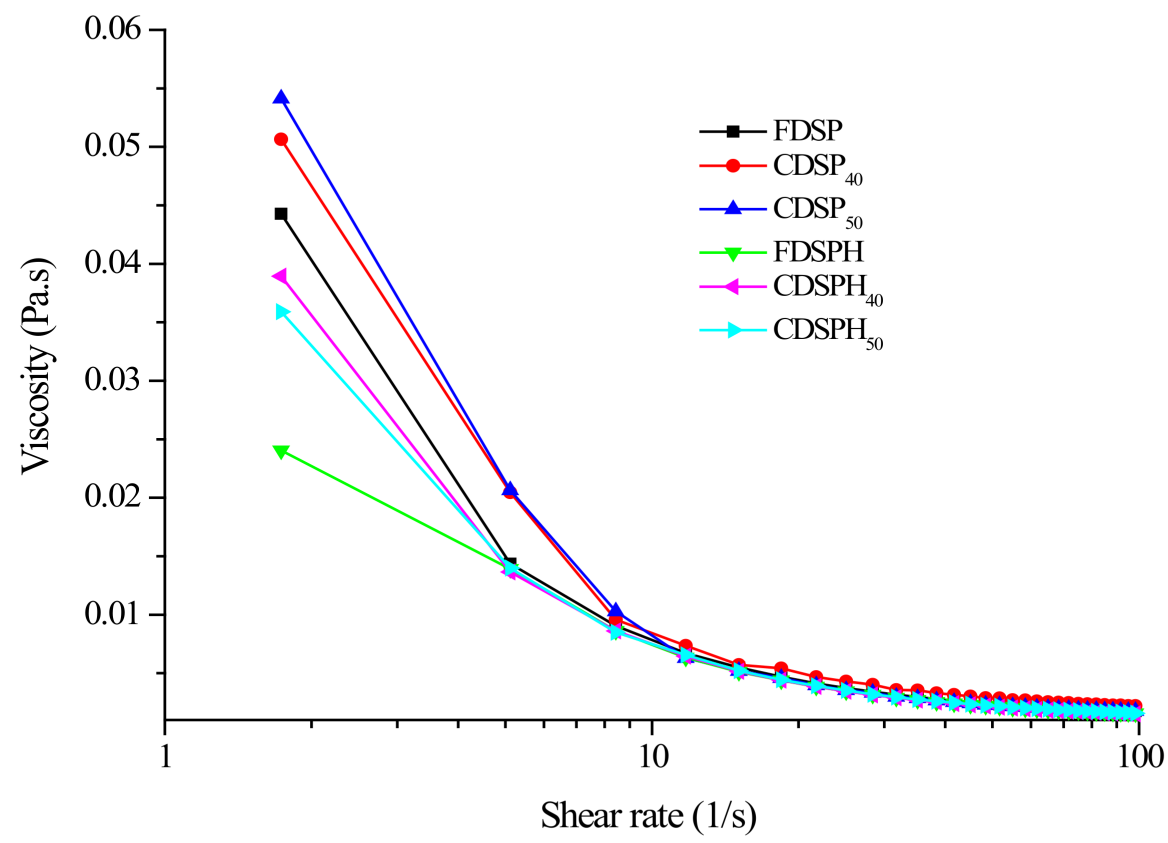

Figure 4. Apparent viscosity of freeze- and convectively-dried SP and SPH.

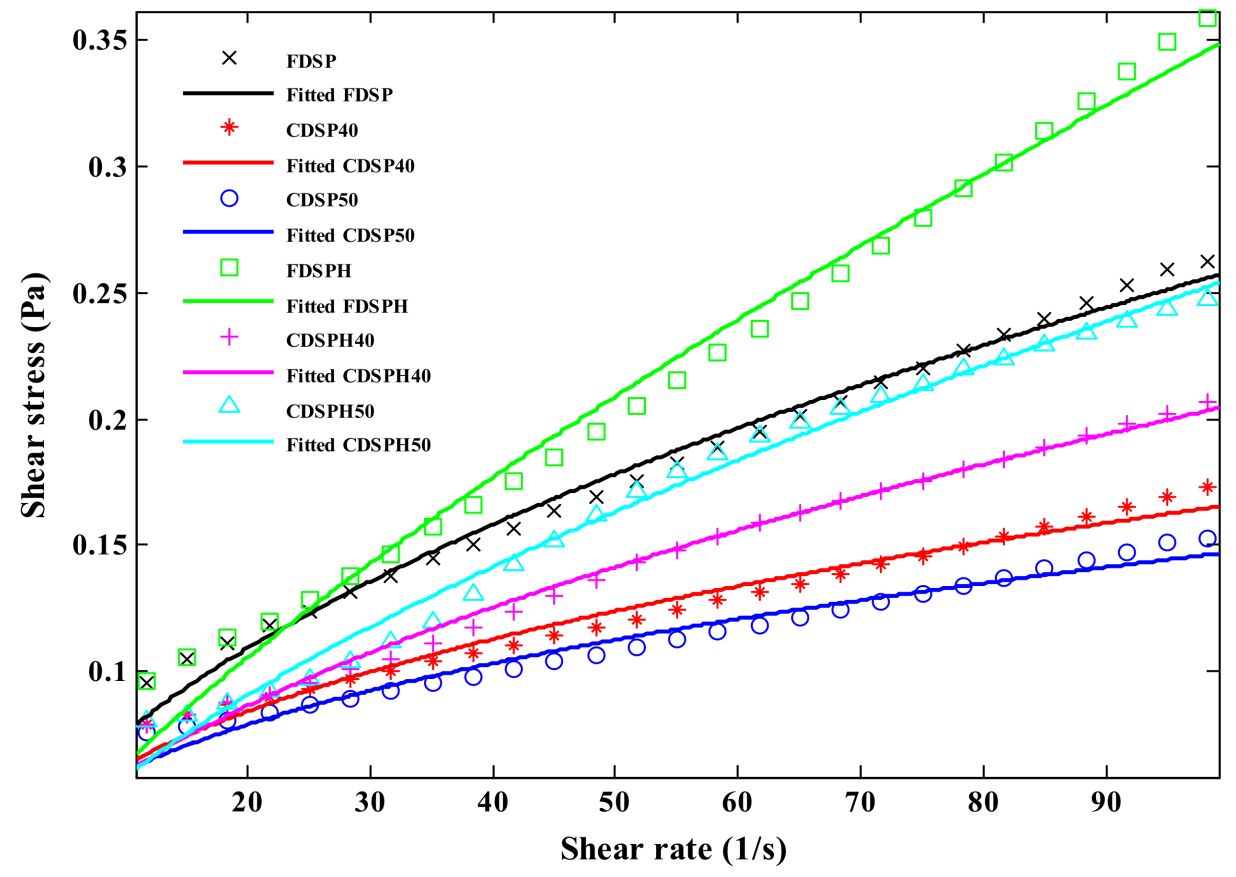

Figure 5. Values of shear stress against shear rate for freeze- and convectively-dried SP and SPH. 
Table 2. Power law constants and goodness of fit for freeze- and convectively-dried SP and SPH.

\begin{tabular}{|c|c|c|c|c|c|c|}
\hline \multirow{2}{*}{ Sample } & \multirow{2}{*}{ Consistency Coefficient -K (Pa.s) } & \multirow{2}{*}{ Flow Behavior Index- n } & \multicolumn{4}{|c|}{ Goodness of Fit } \\
\hline & & & $\mathbf{R}^{2}$ & $\operatorname{Adj} . R^{2}$ & SSE & RMSE \\
\hline FDSP & $0.0219 \pm 0.0002^{a}$ & $0.5355 \pm 0.014^{c}$ & 0.988 & 0.987 & 0.0008 & 0.0057 \\
\hline $\mathrm{CDSP}_{40}$ & $0.0238 \pm 0.0010^{\mathrm{a}}$ & $0.4220 \pm 0.009^{d}$ & 0.972 & 0.971 & 0.0006 & 0.0049 \\
\hline $\mathrm{CDSP}_{50}$ & $0.0247 \pm 0.0008^{a}$ & $0.3874 \pm 0.021^{\mathrm{d}}$ & 0.966 & 0.965 & 0.0005 & 0.0044 \\
\hline FDSPH & $0.0112 \pm 0.0020^{\mathrm{c}}$ & $0.7464 \pm 0.032^{\mathrm{a}}$ & 0.986 & 0.985 & 0.0024 & 0.0099 \\
\hline $\mathrm{CDSPH}_{40}$ & $0.0172 \pm 0.0013^{b}$ & $0.5383 \pm 0.018^{c}$ & 0.989 & 0.989 & 0.0004 & 0.0043 \\
\hline $\mathrm{CDSPH}_{50}$ & $0.0131 \pm 0.0015^{c}$ & $0.6445 \pm 0.008^{b}$ & 0.988 & 0.988 & 0.0010 & 0.0063 \\
\hline
\end{tabular}

Note: Results (average of three (3) times) in one column sharing the various letter-superscript exhibit significantly different $(p<0.05)$. $\mathbf{R}^{2}$ : Coefficient of determination; SSE: Sum of squared errors; RMSE: Root mean square error.

Further, convection drying of SP and SPH (especially at $50{ }^{\circ} \mathrm{C}$ ) considerably resulted in a higher viscosity than the respective freeze-dried preparations (at shear rate ranged between 2 and $10 \mathrm{~s}^{-1}$ ), which was also consistent with the trend of $\mathrm{EA}_{\text {index }}$ and $\mathrm{ES}_{\text {index }}$ (Figure $\left.3 \mathrm{~A}, \mathrm{~B}\right)$. The high viscosity realized, is mostly due to alterations in protein/hydrolysate structure upon convection drying. Such alterations expose the buried hydrophobic/hydrophilic clusters and sites to surrounding water, and then improves the binding (to $\mathrm{H}_{2} \mathrm{O}$ molecules) efficiency. Additionally, with increased shear rate (10-100 s ${ }^{-1}$ ) all dried samples had very close viscosity values. Results also indicated that SPHs had lower viscosities than the respective SPs preparations at a shear rate of $2-10 \mathrm{~s}^{-1}$. This phenomenon may be credited to the reduction in the hydrodynamic radius of SPHs, which impaired their interaction with $\mathrm{H}_{2} \mathrm{O}$ [43], thus lowering the viscosity of freeze- and convectively-dried $\mathrm{SPH}$. These data were consistent with the findings of $\mathrm{P}_{\text {sizing }}$ and $\mathrm{M}_{\text {weight }}$ in the current study. Such an outcome agreed with the observation of Lamsal et al. [25] who observed that soy protein possessed higher apparent viscosity relative to its hydrolysates obtained by localized enzymolysis.

Regarding power law constants (consistency coefficient $-\mathrm{K}$, flow behavior index- $\mathrm{n}$ ), the difference in the mentioned constants was assessed, which was influenced by the dehydration techniques and enzymolysis, applying Equation (7). The power-law equation presented a strong fit for the rheological curves (shear stress against shear rate) of freezeand convectively-dried SP and SPH (Figure 5). This excellent fit was supported by a high value of $R^{2}(\geq 0.966)$ and adj. $R^{2}(\geq 0.965)$ and a low value of SSE $(\leq 0.0024)$ and RMSE $(\leq 0.0099)$ (Table 2$)$, demonstrating that the existing model accurately described the rheological attributes of all preparations. The maximal $\mathrm{K}$ value was recorded for $\mathrm{CDSP}_{50}$ dispersion, followed by $\mathrm{CDSP}_{40}, \mathrm{FDSP}, \mathrm{CDSPH}_{40}, \mathrm{CDSPH}_{50}$, and $\mathrm{FDSPH}$, confirming the order of viscosity (Figure 4 ) for the respective preparations. Furthermore, SPHs exhibited lower $\mathrm{K}$ values $(p<0.05)$ reference to SP isolates, leading to thinner dispersions. This loss in consistency coefficient upon enzymolysis is mostly attributed to the improved $\mathrm{P}_{\text {solubility }}$ (as noted in Figure 1) [25], and the reduction in $P_{\text {sizing }}$ (as observed in Table 1) [42] of the respective samples. Furthermore, dehydrated SPs and SPHs dispersions showed a non-Newtonian pseudoplastic behavior $(n<1)$ with shear thinning. The $n$ values of SP and SPH preparations were in order $\mathrm{CDSP}_{50}<\mathrm{CDSP}_{40}<\mathrm{FDSP}<\mathrm{CDSPH}_{40}<\mathrm{CDSPH}_{50}$ $<$ FDSPH $(p<0.05)$, confirming that dehydration methods and enzymolysis remarkably influenced the flowing behavior of investigated samples. These alterations can possibly be linked to the modification and/or denaturation of SPs/SPHs conformation following the drying process. Finally, freeze-dried samples had lower viscosity and consistency coefficient, but enhanced flow behavior index (of dispersions), indicating that FD samples (observably FDSPH) can find applications in existing food formulations.

\section{6. $M_{\text {weight }}$ Analysis}

The $\mathrm{M}_{\text {weight }}$ distribution of freeze- and convectively-dried SP and SPH (Table 3) showed alterations in SP and SPH compositions with respect to the dehydration techniques used. Relative to oven-dried preparations, the proportion of higher $\mathrm{M}_{\text {weight }}(\geq 5000 \mathrm{Da})$ of the freeze-dried samples, FDSP and FDSPH, was considerably higher. However, small 
proteins/peptides in FDSP ( 9\%) and FDSPH ( 73\%) were noticeably low in $\leq 3000 \mathrm{Da}$ fractions compared with the respective oven-dried preparations $(p<0.05)$. These modifications indicated that oven drying resulted in a lower $\mathrm{M}_{\text {weight }}$ of SP and SPH and altered their tertiary structure. This observation can particularly be associated with the generation of ice crystal(s) during freeze drying, reflecting the aggregates of particles and recombining into bigger $\mathrm{M}_{\text {weight }}$ [30]. Further, freeze and convectively $\left(40\right.$ and $50{ }^{\circ} \mathrm{C}$ ) dried SPH were significantly rich in $\leq 3000$ Da fractions than the SP powders, which improved by 87.57, 87.42 , and $80.52 \%$, respectively, demonstrating that lower $\mathrm{M}_{\text {weight }}$ of SPs was formed during proteolysis. This may clearly be due to the breakdown of the molecular conformation of SP, leading to the release and/or formation of small-sized hydrolysates/peptides during enzymolysis [13]. A similar effect on $\mathbf{M}_{\text {weight }}$ due to proteolysis was also observed [44]. The investigations of $\mathrm{M}_{\text {weight }}$ were also in agreement with the data of $\mathrm{P}_{\text {sizing }}$ (Table 1 ).

Table 3. $\mathrm{M}_{\text {weight }}(\%)$ of freeze- and convectively-dried SP and SPH.

\begin{tabular}{ccccccc}
\hline MW (Da) & FDSP & CDSP $_{\mathbf{4 0}}$ & CDSP $_{\mathbf{5 0}}$ & FDSPH & CDSPH $_{\mathbf{4 0}}$ & CDSPH $_{\mathbf{5 0}}$ \\
\hline$>10,000$ & 25.83 & 16.10 & 13.54 & 8.27 & 3.46 & 1.24 \\
$10,000-5000$ & 55.91 & 55.95 & 53.23 & 7.44 & 5.64 & 6.07 \\
$5000-3000$ & 9.20 & 16.79 & 15.79 & 11.39 & 2.15 & 3.17 \\
$3000-1000$ & 7.54 & 8.31 & 11.02 & 17.22 & 18.53 & 14.48 \\
$1000-500$ & 1.28 & 1.84 & 2.15 & 18.50 & 23.19 & 23.56 \\
$<500$ & 0.24 & 1.01 & 4.27 & 37.18 & 47.03 & 51.48 \\
\hline
\end{tabular}

\subsection{Correlation Analysis}

In this investigation, the effect of dehydration techniques on the physical, functional, and rheological attributes of SP and SPH was examined. To further elucidate the relationship (intrinsically) between these attributes of dehydrated SPs and SPHs, correlational analysis was performed (Table 4 ). Results of $B_{\text {index }}$ exhibited negative correlation with $\mathrm{P}_{\text {sizing }}(\mathrm{r}=-0.949), \mathrm{B}_{\text {density }}(\mathrm{r}=-0.919)$, and turbidity $(\mathrm{r}=-0.945)$. Inferring from this (high correlation values) is that, $B_{\text {index }}$ affected the above parameters and vice versa. This demonstrated that the increase in browning index corresponded with reduction in $\mathrm{P}_{\text {sizing, }}$ bulk density and turbidity. Similarly, a noticed reduction in $\mathrm{P}_{\text {sizing }}$ was accountable for nearly 98 and $95 \%$ of the decrease in $B_{\text {density }}$ and turbidity respectively, whereas with a corresponding increase (91\%) in $\mathrm{ES}_{\text {index }}$. Such outcomes are typically ascribed to the effect of the convection oven drying and proteolysis, which brought about a decrease in $P_{\text {sizing }}[13,27]$, and afterward unfolding of SPs and SPHs structure to display the observed relationship. Moreover, the increase in solubility remarkably contributed to enhancing $\mathrm{F}_{\text {capacity }}, \mathrm{F}_{\text {stability }}$ and the flow behavior index (n) of SPs and SPHs, which led to a considerable reduction in the $\mathrm{EA}_{\text {index }}$ and consistency coefficient $(\mathrm{K})$. This can be linked to the increased solubility of SP and its hydrolysates as a result of increases in their positive/negative net charges in solutions [1], which enhanced foam formation (foamability) and interfacial films [38] with sufficient strength to stabilize the foams [45]. Reductions in $\mathrm{EA}_{\text {index }}$ and $\mathrm{K}$, however, can be explained by the partial alterations and/or denaturation of the protein/hydrolysate conformation, resulting in a decrease in oil $/ \mathrm{H}_{2} \mathrm{O}$ interfacial tension [39] and $\mathrm{P}_{\text {sizing }}$ of dehydrated SPs and SPHs [42]. Finally, correlational analysis evidenced that dehydration methods altered the physical and rheological traits as well as functionality of SPs and SPHs. 
Table 4. Correlation matrix of the physical, functional and rheological parameters of freeze- and convectively-dried SP and SPH.

\begin{tabular}{|c|c|c|c|c|c|c|c|c|c|c|c|}
\hline Variables & $B_{\text {index }}$ & $\mathbf{P}_{\text {sizing }}$ & $\mathbf{B}_{\text {density }}$ & $\mathrm{T}_{\text {tur }}$ & $\mathbf{P}_{\text {Solubility }}$ & $F_{\text {capacity }}$ & $\mathbf{F}_{\text {stability }}$ & $\mathbf{E A}_{\text {index }}$ & $\mathrm{ES}_{\text {index }}$ & $\mathbf{K}$ & n \\
\hline$B_{\text {index }}$ & 1 & & & & & & & & & & \\
\hline$P_{\text {sizing }}$ & $-0.949 *$ & 1 & & & & & & & & & \\
\hline $\mathrm{B}_{\text {density }}$ & $-0.919 *$ & $0.980 *$ & 1 & & & & & & & & \\
\hline $\mathrm{T}_{\text {tur }}$ & $-0.945^{*}$ & $0.953 *$ & $0.963 *$ & 1 & & & & & & & \\
\hline$P_{\text {Solubility }}$ & 0.512 & -0.347 & -0.390 & -0.594 & 1 & & & & & & \\
\hline $\mathrm{F}_{\text {capacity }}$ & 0.741 & -0.703 & -0.732 & $-0.869 *$ & $0.872 *$ & 1 & & & & & \\
\hline $\mathrm{F}_{\text {stability }}$ & 0.757 & -0.696 & -0.745 & $-0.871 *$ & 0.895 * & 0.985 * & 1 & & & & \\
\hline EA $_{\text {index }}$ & -0.273 & 0.079 & 0.105 & 0.318 & $-0.929 *$ & -0.692 & -0.713 & 1 & & & \\
\hline $\mathrm{ES}_{\text {index }}$ & 0.805 & $-0.909 *$ & $-0.825 *$ & -0.797 & 0.133 & 0.553 & 0.480 & 0.085 & 1 & & \\
\hline K & -0.721 & 0.586 & 0.647 & 0.781 & $-0.933 *$ & $-0.904 *$ & $-0.959 *$ & 0.789 & -0.299 & 1 & \\
\hline $\mathrm{n}$ & 0.502 & -0.324 & -0.399 & -0.562 & $0.961 *$ & 0.797 & $0.864 *$ & $-0.901 *$ & 0.024 & $-0.955 *$ & 1 \\
\hline
\end{tabular}

Note: ' + ' or ' - ' sign represent positive and negative correlation, respectively; ${ }^{*}$ sign represents significant at $p<0.05 ; \mathrm{K}$-consistency coefficient; $\mathrm{n}$-flow behavior index; data of PSolubility, Fcapacity, Fstability, EAindex and ESindex were selected at $\mathrm{pH} 8.0$ for correlation analysis.

\section{Conclusions}

In this research, SPs and SPHs were prepared using two drying approaches, i.e., freeze drying and convection oven drying (at 40 and $50{ }^{\circ} \mathrm{C}$ ). The luminosity, $\mathrm{P}_{\text {sizing }}, \mathrm{B}_{\text {density }}$, and turbidity of freeze-dried SP and SPH were substantially higher, reference to convectivelydried powders; while a lower $\mathrm{B}_{\text {index }}$ was observed $(p<0.05)$. High solubility, and foaming activity/stability of SP and its hydrolysate, obtained following freeze drying, makes them suitable for food preparations at varied $\mathrm{pH}$ values. The high emulsion traits of convectivelydried SPs and SPHs, highpoints the potential for using such in acidic/non-acidic food emulsions. Furthermore, freeze drying resulted in lower viscosity and consistency coefficient, compared with convection drying; whilst greater flow behavior index of dispersions was noticed. There were changes in the rheological and functional characteristics of SPs and SPHs due to the dehydration methods as the correlational analysis confirmed that solubility was negatively interrelated with $\mathrm{EA}_{\text {index }}$ and consistency coefficient $(\mathrm{K})$; whereas it showed a positive interrelation with $\mathrm{F}_{\text {capacity }}, \mathrm{F}_{\text {stability, }}$, and flow behavior index (n).

Author Contributions: Experimental design, Methodology, Data analysis, Writing - review and editing, M.D. and A.T.P.; Visualization, Funding acquisition, R.S.; Funding acquisition, E.K.; Visualization, A.T.P.; Conceptualization, review/editing, B.K.M.; Funding acquisition, Supervision, Resources, R.H.; Data analysis, Visualization, H.W.; Conceptualization, Validation, M.F. All authors have read and agreed to the published version of the manuscript.

Funding: This research received no external funding.

Institutional Review Board Statement: Not applicable.

Informed Consent Statement: Not applicable.

Data Availability Statement: Available upon request from the corresponding author.

Acknowledgments: This study was supported by the Primary Research and Development Plan (2016YFD0401401); and National Primary Research and Development Plan of Jiangsu Province (BE2016352, BE2016355). Taif University Researchers Supporting Project Number (TURSP-2020/307), Taif University, Taif, Saudi Arabia.

Conflicts of Interest: The authors declared no conflict of interest.

\section{References}

1. Shen, Y.; Tang, X.; Li, Y. Drying methods affect physicochemical and functional properties of quinoa protein isolate. Food Chem. 2021, 339, 127823. [CrossRef] [PubMed]

2. FAOSTAT. Crop Production Statistics; FAO: Rome, Italy, 2021. Available online: https://faostat.fao.org/site/567/default.aspx\# ancor (accessed on 19 December 2021).

3. Dorrell, D.G.; Vick, B.A. Properties and Processing of Oilseed Sunflower. In Sunflower: Technology and Production; Schneiter, A.A., Ed.; Technology and Production, American Society of Agronomy: Madison, WI, USA, 1997; pp. 709-745. 
4. González-Pérez, S.; Vereijken, J.M. Sunflower proteins: Overview of their physicochemical, structural and functional properties. J. Sci. Food Agric. 2007, 87, 2173-2191. [CrossRef]

5. Gassmann, B. Preparation and application of vegetable proteins, especially proteins from sunflower seed, for human consumption. An approach. Nahrung 1983, 27, 351-369. [CrossRef] [PubMed]

6. Megías, C.; Pedroche, J.; del Mar Yust, M.; Alaiz, M.; Girón-Calle, J.; Millán, F.; Vioque, J. Purification of angiotensin converting enzyme inhibitory peptides from sunflower protein hydrolysates by reverse-phase chromatography following affinity purification. LWT Food Sci. Technol. 2009, 42, 228-232. [CrossRef]

7. Ren, J.; Zheng, X.Q.; Liu, X.L.; Liu, H. Purification and characterization of antioxidant peptide from sunflower protein hydrolysate Food Technol. Biotechnol. 2010, 48, 519-523.

8. Taha, F.S.; Mohamed, S.S.; Wagdy, S.M.; Mohamed, G.F. Antioxidant and antimicrobial activities of enzymatic hydrolysis products from sunflower protein isolate. World Appl. Sci. J. 2013, 21, 651-658.

9. Malik, M.A.; Saini, C.S. Improvement of functional properties of sunflower protein isolates near isoelectric point: Application of heat treatment. LWT Food Sci. Technol. 2018, 98, 411-417. [CrossRef]

10. Provansal, M.M.P.; Cuq, J.A.; Cheftel, J.C. Chemical and nutritional modifications of sunflower proteins due to alkaline processing. formation of amino acid cross-links and isomerization of lysine residues. J. Agric. Food Chem. 1975, 23, 938-943. [CrossRef] [PubMed]

11. Minones-Conde, J.; Yust, M.M.; Pedroche, J.; Millán, F.; Rodríguez-Patino, J.M. Effect of enzymatic treatment of extracted sunflower proteins on solubility, amino acid composition, and curface activity. J. Agric. Food Chem. 2005, 53, 8038-8045. [CrossRef] [PubMed]

12. Mintah, B.; He, R.; Dabbour, M.; Xiang, J.; Akomeah, A.; Ma, H. Techno-functional attribute and antioxidative capacity of edible insect protein preparations and hydrolysates thereof: Effect of multiple mode sonochemical action. Ultrason. Sonochem. 2019, 58, 104676. [CrossRef]

13. Mintah, B.; He, R.; Dabbour, M.; Xiang, J.; Hui, J.; Agyekum, A.; Ma, H. Characterization of edible soldier fly protein and hydrolysate altered by multiple-frequency ultrasound: Structural, physical, and functional attributes. Process Biochem. 2020, 95, 157-165. [CrossRef]

14. Alinejad, M.; Motamedzadegan, A.; Rezaei, M.; Regenstein, J.M. The impact of drying method on the functional and antioxidant properties of whitecheek shark (Carcharhinus dussumieri) protein hydrolysates. J. Food Process. Preserv. 2016, 41, e12972. [CrossRef]

15. Deshwal, G.K.; Singh, A.K.; Kumar, D.; Sharma, H. Effect of spray and freeze drying on physico-chemical, functional, moisture sorption and morphological characteristics of camel milk powder. LWT Food Sci. Technol. 2020, 134, 110117. [CrossRef]

16. Brishti, F.H.; Chay, S.Y.; Muhammad, K.; Ismail-Fitry, M.R.; Zarei, M.; Karthikeyan, S.; Saari, N. Effects of drying techniques on the physicochemical, functional, thermal, structural and rheological properties of mung bean (Vigna radiata) protein isolate powder. Food Res. Int. 2020, 138, 109783. [CrossRef] [PubMed]

17. Joshi, M.; Adhikari, B.; Aldred, P.; Panozzo, J.F.; Kasapis, S. Physicochemical and functional properties of lentil protein isolates prepared by different drying methods. Food Chem. 2011, 129, 1513-1522. [CrossRef]

18. Gong, K.; Shi, A.; Liu, H.; Liu, L.; Hu, H.; Adhikari, B.; Wang, Q. Emulsifying properties and structure changes of spray and freeze-dried peanut protein isolate. J. Food Eng. 2016, 170, 33-40. [CrossRef]

19. Chen, C.; Chi, Y.; Xu, W. Comparisons on the functional properties and antioxidant activity of spray-dried and freeze-dried egg white protein hydrolysate. Food Bioprocess Technol. 2012, 5, 2342-2352. [CrossRef]

20. Dabbour, M.; Xiang, J.; Mintah, B.; He, R.; Jiang, H.; Ma, H. Localized enzymolysis and sonochemically modified sunflower protein: Physical, functional and structure attributes. Ultrason. Sonochem. 2020, 63, 104957. [CrossRef]

21. Dabbour, M.; Adingba, E.; Mintah, B.; He, R.; Jiang, H.; Ma, H. Proteolysis kinetics and structural characterization of ultrasonic pretreated sunflower protein. Process Biochem. 2020, 94, 198-206. [CrossRef]

22. Ding, P.; Ling, Y.S. Browning assessment methods and polyphenol oxidase in UV-C irradiated Berangan banana fruit. Int. Food Res. J. 2014, 21, 1667-1674.

23. Lowry, O.; Rosebrough, N.; Farr, L.; Randall, R. Protein measurement with the Folin phenol reagent. J. Biol. Chem. 1951, 193, 265-275. [CrossRef]

24. Liu, Y.; Li, X.; Chen, Z.; Yu, J.; Wang, F.; Wang, J. Characterization of structural and functional properties of fish protein hydrolysates from surimi processing by-products. Food Chem. 2014, 151, 459-465. [CrossRef] [PubMed]

25. Lamsal, B.P.; Jung, S.Ã.; Johnson, L.A. Rheological properties of soy protein hydrolysates obtained from limited enzymatic hydrolysis. LWT_Food Sci. Technol. 2007, 40, 1215-1223. [CrossRef]

26. Wang, Y.; Zhang, Z.; He, R.; Kumah, B.; Dabbour, M.; Qu, W.; Liu, D.; Ma, H. Proteolysis efficiency and structural traits of corn gluten meal: Impact of different frequency modes of a low-power density ultrasound. Food Chem. 2021, 344, 128609. [CrossRef] [PubMed]

27. Ghribi, A.M.; Gafsi, I.M.; Blecker, C.; Danthine, S.; Attia, H.; Besbes, S. Effect of drying methods on physico-chemical and functional properties of chickpea protein concentrates. J. Food Eng. 2015, 165, 179-188. [CrossRef]

28. Ghribi, A.M.; Gafsi, I.M.; Sila, A.; Blecker, C.; Danthine, S.; Attia, H.; Bougatef, A.; Besbes, S. Effects of enzymatic hydrolysis on conformational and functional properties of chickpea protein isolate. Food Chem. 2015, 187, 322-330. [CrossRef] [PubMed]

29. Wasswa, J.; Tang, J.; Gu, X.; Yuan, X. Influence of the extent of enzymatic hydrolysis on the functional properties of protein hydrolysate from grass carp (Ctenopharyngodon idella) skin. Food Chem. 2007, 104, 1698-1704. [CrossRef] 
30. Yao, Y.; Zhao, G.; Yan, Y.; Chen, C.; Sun, C.; Zou, X.; Jin, Q.; Wang, X. Effects of freeze drying and spray drying on the microstructure and composition of milk fat globules. RSC Adv. 2016, 6, 2520-2529. [CrossRef]

31. Rudra, S.G.; Sethi, S.; Jha, S.K.; Kumar, R. Physico-chemical and functional properties of cowpea protein isolate as affected by the dehydration technique. Legum. Res. 2016, 39, 370-378. [CrossRef]

32. Zisu, B.; Lee, J.; Chandrapala, J.; Bhaskaracharya, R.; Palmer, M.; Kentish, S.; Ashokkumar, M. Effect of ultrasound on the physical and functional properties of reconstituted whey protein powders. J. Dairy Res. 2011, 78, 226-232. [CrossRef]

33. Thiansilakul, Y.; Benjakul, S.; Shahidi, F. Compositions, functional properties and antioxidative activity of protein hydrolysates prepared from round scad (Decapterus maruadsi). Food Chem. 2007, 103, 1385-1394. [CrossRef]

34. Tavano, O.L. Enzymatic protein hydrolysis using protease: An important tool for food biotechnology. J. Mol. Catal. B Enzym. 2013, 90, 1-11. [CrossRef]

35. Zeng, Q.; Zhang, M.; Adhikari, B.P.; Mujumdar, A.S. Effect of drying processes on the functional properties of collagen peptides produced from chicken skin. Dry. Technol. 2013, 31, 1653-1660. [CrossRef]

36. Bao, Z.; Zhao, Y.; Wang, X.; Chi, Y.-J. Effects of degree of hydrolysis (DH) on the functional properties of egg yolk hydrolysate with alcalase. J. Food Sci. Technol. 2017, 54, 669-678. [CrossRef] [PubMed]

37. Lin, N.; Liu, B.; Liu, Z.; Qi, T. Effects of different drying methods on the structures and functional properties of phosphorylated Antarctic krill protein. J. Food Sci. 2020, 85, 1-10. [CrossRef]

38. Chen, C.; Chi, Y.; Zhao, M.; Xu, W. Influence of degree of hydrolysis on functional properties, antioxidant and ACE Inhibitory activities of egg white protein hydrolysate. Food Sci. Biotechnol. 2012, 21, 27-34. [CrossRef]

39. Gbogouri, G.A.; Linder, M.; Fanni, J.; Parmentier, M. Influence of hydrolysis degree on the functional properties of salmon byproducts hydrolysates. J. Food Sci. 2004, 69, 615-622. [CrossRef]

40. Elavarasan, K.; Shamasundar, B.A. Effect of oven drying and freeze drying on the antioxidant and functional properties of protein hydrolysates derived from freshwater fish (Cirrhinus mrigala) using papain enzyme. J. Food Sci. Technol. 2016, 53, 1303-1311. [CrossRef]

41. Musa, K.H.; Abdullah, A.; Mustapha, W.-A.W. Functional properties of surimi related to drying methods. Malays. Appl. Biol. 2005, 34, 83-87.

42. Yanjun, S.; Jianhang, C.; Shuwen, Z.; Hongjuan, L.; Jing, L.; Lu, L.; Uluko, H.; Yanling, S.; Wenming, C.; Wupeng, G. Effect of power ultrasound pre-treatment on the physical and functional properties of reconstituted milk protein concentrate. J. Food Eng. 2014, 124, 11-18. [CrossRef]

43. Krešić, G.; Jambrak, A.R.; Lelas, V.; Herceg, Z. Influence of innovative technologies on rheological and thermophysical properties of whey proteins and guar gum model systems. Mljekarstvo 2011, 61, 64-78.

44. You, L.; Zhao, M.; Cui, C.; Zhao, H.; Yang, B. Effect of degree of hydrolysis on the antioxidant activity of loach (Misgurnus anguillicaudatus) protein hydrolysates. Innov. Food Sci. Emerg. Technol. 2009, 10, 235-240. [CrossRef]

45. Dabbour, M.; He, R.; Mintah, B.; Xiang, J.; Ma, H. Changes in functionalities, conformational characteristics and antioxidative capacities of sunflower protein by controlled enzymolysis and ultrasonication action. Ultrason. Sonochem. 2019, 58, 104625. [CrossRef] [PubMed] 